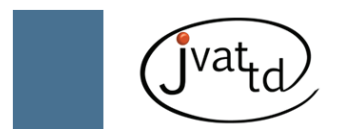

\title{
Intestinal parasitic infections in HIV/AIDS patients: epidemiological, nutritional and immunological aspects
}

\author{
Amâncio FAM (1), Pascotto VM (1), Souza LR (1), Calvi SA (1), Pereira PCM (1)
}

(1) Department of Tropical Diseases, Botucatu Medical School, São Paulo State University (UNESP - Univ Estadual Paulista), Botucatu, São Paulo State, Brazil.

\begin{abstract}
This study applied a socioeconomic questionnaire designed to evaluate the frequency of intestinal parasites and characterize epidemiological, nutritional, and immunological variables in 105 HIV/AIDS patients - with and without parasitic infections, attending the Day Hospital in Botucatu, UNESP, from 2007 to 2008. Body mass index was calculated and the following tests performed: parasitological stool examinations; eosinophil, lgE, $\mathrm{CD}^{+} \mathrm{T}$ and $\mathrm{CD} 8^{+} \mathrm{T}$ lymphocyte cell counts; albumin test; viral load measure; and TNF-a, IFN- $\gamma$, IL-2, IL-5 and IL-10 cytokine levels. Results were positive for parasitic intestinal infections in $12.4 \%$ of individuals. Most patients had good socioeconomic conditions with basic sanitation, urban dwellings, treated water supply and sewage, good nutritional and immunological status and were undergoing HAART. Parasites were found at the following frequencies: Entamoeba - five patients (38.5\%), Giardia lamblia - four (30.7\%), Blastocystis hominis - three (23.0\%), Endolimaxnana - two (15.4\%), and Ascaris lumbricoides - one (7.7\%). There were no significant differences between the two groups for eosinophils, albumin, IgE, CD4 ${ }^{+} \mathrm{T}$ and $\mathrm{CD} 8^{+} \mathrm{T}$ lymphocytes, INF- $\gamma$, IL-2, or IL-10. Most patients also showed undetectable viral load levels. Significant differences were found for TNF-a and IL-5. These results show the importance of new studies on immunodeficient individuals to increase understanding of such variables.
\end{abstract}

Key words: HIV/AIDS, enteroparasites, nutrition, immunology, cytokines.

\section{INTRODUCTION}

The number of people living with the human immunodeficiency virus (HIV) has increased as a result of new infections each year and the beneficial effect of highly-active antiretroviral therapy (HAART) (1). Since the emergence of AIDS, clinical alterations related to the gastrointestinal tract have been highly prevalent, of which diarrheic conditions associated to parasitic infections are noteworthy (2). Many studies have shown that some intestinal parasites were frequently associated with severe diarrhea in HIV patients, both in developed and developing countries (2-8). Socioeconomic and cultural factors have carefully been studied for the impact that they may have on the onset of enteroparasitosis in general and in HIV-infected patients (9).

In the last few years, advances in HAART have led to improvements in immunological state with a resulting reduction in the frequency of certain intestinal parasites (10-13). Recent studies have also shown that prolonged use of HAART, particularly of protease inhibitors, has an important impact on user nutritional status. The relationship between infections caused by intestinal parasites and some nutritional indicators has been proven in numerous studies involving nutritional status, infection prevalence and intensity (14-20). Malnutrition has a serious influence on immunity aspects, including 
the production of cytokines and antibodies, particularly Th2 profile (21-23). Recent research has also reported that intestinal helminth infections result in immune responses that involve cytokines produced by Th 2 cells, with IgE production, eosinophilia, and mastocytosis (2427).

Considering the high frequency of parasitic intestinal diseases in individuals with HIV or AIDS, many of which are opportunistic in character and seriously affect patients, new studies are required to investigate the relationship between such infections and the immunological response in these individuals, as well as the nutritional effects of these diseases in this population. Hence, this study aimed at evaluating the prevalence of enteroparasitosis in individuals with HIV or AIDS and at correlating the epidemiological, clinical, nutritional and immunologic variables which could be affected by the presence of intestinal parasites in these patients.

\section{PATIENTS AND METHODS}

\section{Patients}

One-hundred and five male and female individuals were selected. They were over 18 years old, had HIV diagnosis confirmed by western blott and were treated at the Specialized Outpatient Service and Day Hospital Professor Emeritus Domingos Alves Meira, UNESP, between March 2007 and June 2008. All were interviewed using a previously established protocol for collecting personal and socioeconomic data; they also underwent clinical, nutritional, and laboratory evaluation. This research project was approved by the Research Ethics Committee of Botucatu Medical School, according to approval document number 147/2007-CEP.

\section{Clinical evaluation}

Clinical and nutritional data were obtained by the researcher using a preestablished protocol which included personal information, and data on weight, appetite loss or gain, and the presence or absence of vomiting and diarrhea.

\section{Nutritional evaluation}

Weight and height were measured using a standardized technique (28). Body mass index (BMI) was then calculated according to World Health Organization guidelines $(29,30)$.

\section{Laboratory evaluation}

Samples for laboratory analysis were collected as follows: three $10 \mathrm{~g}$ feces samples were collected on alternate days following TF-test $^{\oplus}$ (Immunoassay, USA) kit instructions, and a 2-mL blood sample was collected for eosinophil count; IgE dosage; $\mathrm{CD}^{+}{ }^{+} \mathrm{T}$ cell count; viral load and cytokine quantification.

\section{Parasitological evaluation of feces}

Examination for enteroparasitosis diagnosis was performed using the TF-test ${ }^{\oplus}$ kit (Immunoassay, USA) for protozoan, larvae, and helminth investigation. Three samples of feces were collected on alternate days and processed according to manufacturer's instructions. Each kit has three collection tubes containing formalin, which enable material preservation and dilution. The processing technique included agitating collection tubes to homogenize fecal material, followed by the addition of one drop of neutral colorless detergent, which lyses fat molecules. Later, $3 \mathrm{~mL}$ of ethyl acetate was pipetted, which eliminated fats and much of the detritus, thus providing clean sediment. Next, the three collection tubes were fitted in the set of filters, and the system was centrifuged at 1,500 rpm for two minutes. Supernatant was then discarded and the sediment placed on a slide stained with $2 \%$ Lugol's solution and analyzed using a microscope.

\section{Evaluation of eosinophils}

Global and relative eosinophil counts were performed by using an automated hematology counter ABX Pentra $120^{\circ}$ (Horiba ABX Diagnostics, France). This equipment analyzed eosinophils from a reagent (Eosinofix) which lysed the red cells with reagent action on the cytoplasmic membranes. The leukocytes maintained their original size, and only eosinophils were stained for optical separation. The reference interval was 0 to 500 cells $/ \mathrm{mm}^{3}$.

\section{Albumin evaluation}

Serum albumin level was measured by the dry chemistry colorimetry method. The reference value was $3.5 \mathrm{~g} / \mathrm{dL}$ to $5.0 \mathrm{~g} / \mathrm{dL}$.

\section{IgE determination}

Serum or heparinized plasma and EDTA or frozen samples were used. Analysis was performed by means of $\mathrm{BN}$ systems particle- 
enhanced immunonephelometry, using the $\mathrm{N}$ latex IgE mono assay (Dade Behring Marburg $\mathrm{GmbH}$, EUA). In adults, concentrations of approximately $100 \mathrm{UI} / \mathrm{mL}$ can be considered the upper limit of the reference range.

\section{CD4 ${ }^{+}$T lymphocyte count}

Quantification of $\mathrm{CD}^{+} \mathrm{T}$ lymphocyte subpopulations in peripheral blood was performed by identifying surface antigens using flow cytometry. The Tritest ${ }^{\mathrm{TM}}$ anti-CD4-FITC/ CD8 PE/CD3 PerCP kit (BD Biosciences, USA) and truCount ${ }^{\mathrm{TM}}$ (BD Biosciences, USA) tubes were used, thus enabling cell count in absolute figures by FACSCalibur ${ }^{\mathrm{TM}}$ flow cytometer (BD Biosciences, USA).

\section{Viral load count}

The Versant ${ }^{\circledast}$ HIV-1 RNA 3.0 bDNA system (Bayer Corporation, USA) test was used for direct quantification of type-1 human immunodeficiency virus (HIV-1) RNA in plasma from individuals with HIV-1 by amplification of the signal emitted by the nucleic acid, using a Bayer System 340 bDNA ${ }^{\oplus}$ Analyzer (USA).

\section{Cytokine quantification}

Levels of TNF- $\alpha$, INF- $\gamma$, IL-2, IL-5, and IL-10 cytokines were determined by immunoenzymatic assay (ELISA) using commercial kits (R\&D Systems, USA) according to manufacturer's instructions. Initially, 96-well microplates were sensitized with specific monoclonal anti-TNF- $\alpha$, anti-INF- $\gamma$, anti-IL-2, anti-IL-5, and anti-IL-10 antibodies. Next, positive and negative controls and samples were added (dilution 1:2), and the plates were incubated at ambient temperature for two hours. Then, four washouts were performed with detergent solution containing 2-chloroacetamide $(0.1 \%)$ and detergent solution containing $0.05 \%$ Tween 20 in PBS, pH 7.4. This procedure was repeated until the phase prior to substrate addition. Later, the biotin-coated plates received peroxidase-bonded streptavidin.

After the incubation period, substrate, formed by hydrogen peroxide $(0.02 \%)$ and tetramethylbenzidine (2\%), was added to the plate wells. Reaction was interrupted at ambient temperature using $50 \mu \mathrm{L}$ of $1 \mathrm{M}$ sulphuric acid. Results were evaluated by measuring opticaldensity (OD) at a wave length of $450 \mathrm{~nm}$ using an automated ELISA reader (Titertek
Multiskan). Cytokine concentrations, in $\mathrm{pg} / \mathrm{mL}$, were calculated from the OD results applied to a standard curve of recombinant cytokine used as control, with $5 \mathrm{pg} / \mathrm{mL}$ as the minimum value detectable by the technique.

\section{Statistical Analysis}

A linear generalized model with negative binomial error was used to compare intestinal parasite frequencies.

Analysis of differences between positive and negative individuals (with or without intestinal parasites) in relation to eosinophil, $\mathrm{IgE}, \mathrm{CD} 4^{+}$ $\mathrm{T}$, and $\mathrm{CD}^{+} \mathrm{T}$ values used a generalized linear model with negative binomial error adjusted for each one, thus obtaining $p$ values.

Fisher's exact test was used to study the association between detectable viral load and the presence of intestinal parasites.

The Kruskal-Wallis test was applied for albumin, BMI, and each cytokine, as it was not possible to adjust a normal distribution of errors to these variables, or they did not have constant variance. SAS Version 9.1 was used for statistical analyses.

\section{RESULTS}

\section{Characterization of the Studied Population}

Of the 105 participants, 54 (51.43\%) were male with no statistical difference in gender distribution $(p=0.8522)$. Mean age of noninfected and infected individuals was $40.19 \pm$ 10.39 and $44.15 \pm 10.86$ years, respectively. Mean monthly per capita income was approximately two minimum salaries (approximately US\$ 500 per month). There was a $90 \%$ predominance of white skinned individuals; only $2 \%$ were illiterate; 95.23\% lived in urban areas with basic sanitation; $26.66 \%$ had a vegetable garden as a food sources, and $88.57 \%$ used HAART.

\section{Clinical Evaluation}

All individuals denied the presence of diarrhea, or changes in appetite or weight over the last few months.

\section{Nutritional Evaluation}

\section{Analysis of albumin serum levels}

Albumin serum levels varied from 2.6 to $6.8 \mathrm{~g} /$ dL. There was no significant difference between groups $(p=0.2709)$. 
Table 1. Median albumin and BMI values in the 105 HIV/AIDS individuals treated at the Specialized Outpatient Service and Day Hospital Professor Emeritus Domingos Alves Meira, UNESP, 2007-2008. The $p$ values obtained through the Kruskal-Wallis test to compare positive with negative individuals were 0.2709 and 0.3946 for albumin and BMI, respectively

\begin{tabular}{c|c|c|c}
\hline & Infected & Non-infected & $\boldsymbol{p}<\mathbf{0 . 0 5}$ values for Kruskal-Wallis test \\
\hline Albumin $(\mathrm{g} / \mathrm{dL})$ & 4.41 & 4.4 & 0.2709 \\
\hline BMI $\left(\mathrm{kg} / \mathrm{m}^{2}\right)$ & 25.4 & 23.8 & 0.3946 \\
\hline
\end{tabular}

BMI: body mass index

\section{BMI analysis}

Patient BMI levels varied between 17 and $43.28 \mathrm{~kg} / \mathrm{m}^{2}$ (Table 1). There was no significant difference between groups $(p=0.3946)$.

\section{Nutritional profile}

Nutritional profile characteristics of study individuals were described according to BMI/ WHO nutritional classification. Of the individuals without intestinal parasites, six (6.97\%) showed low weight (BMI: $<18.5 \mathrm{~kg} / \mathrm{m}^{2}$ ), 43 (50\%) were within normal limits (BMI: 18.5 to $24.9 \mathrm{~kg} / \mathrm{m}^{2}$ ), 27 (31.39\%) were pre-obese (BMI: 25.0 to $29.9 \mathrm{~kg} /$ $\mathrm{m}^{2}$ ), seven (8.13\%) were obese I (BMI: 30.0 to 34.9 $\mathrm{kg} / \mathrm{m}^{2}$ ), two (2.32\%) were obese II (BMI: 35.0 to $\left.39.9 \mathrm{~kg} / \mathrm{m}^{2}\right)$, and one $(1.16 \%)$ was obese III $(>40.0$ $\left.\mathrm{kg} / \mathrm{m}^{2}\right)$. Of the individuals with intestinal parasites, none showed low weight (BMI: $<18.5 \mathrm{~kg} / \mathrm{m}^{2}$ ), five (50\%) were within normal limits (BMI: 18.5 to $24.9 \mathrm{~kg} / \mathrm{m}^{2}$ ), four (40\%) were pre-obese (BMI: 25.0 to $29.9 \mathrm{~kg} / \mathrm{m}^{2}$ ), one (10\%) was obese I (BMI: 30.0 to $34.9 \mathrm{~kg} / \mathrm{m}^{2}$ ), and none was obese II (BMI: 35.0 to $\left.39.9 \mathrm{~kg} / \mathrm{m}^{2}\right)$ or obese III $\left(>40.0 \mathrm{~kg} / \mathrm{m}^{2}\right)$.

\section{Evaluation of intestinal parasites}

Of the 105 analyzed individuals, 92 (87.61\%) showed negative results, and 13 (12.38\%) showed positive results. Entamoeba coli was found in five (38.5\%) samples, followed by Giardia lamblia in four (30.7\%), Blastocystis hominis in three

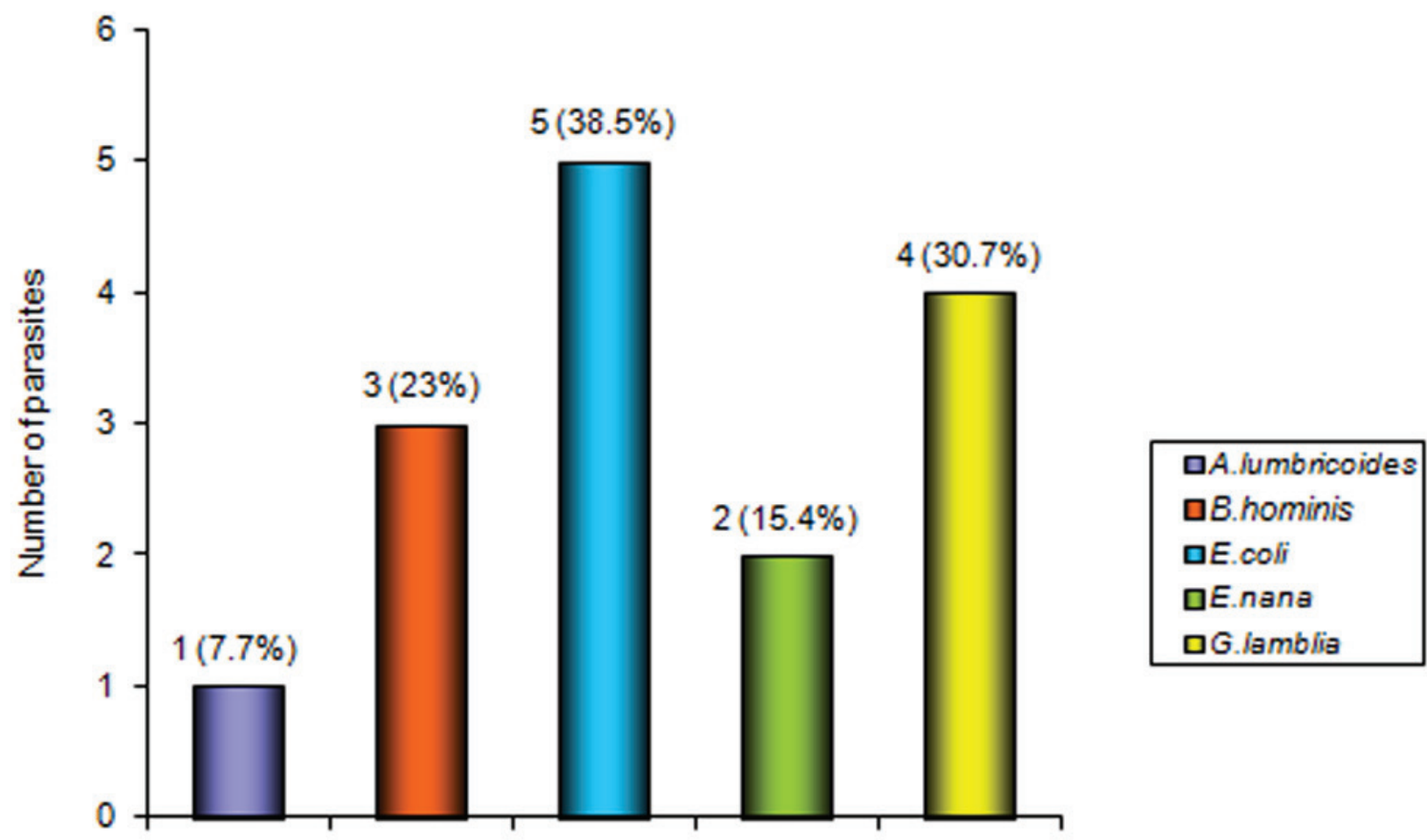

Figure 1. Number of intestinal parasites in HIV/AIDS individuals treated at the Specialized Outpatient Service and Day Hospital Professor Emeritus Domingos Alves Meira, UNESP, 2007-2008. The $p$ value obtained by adjusted negative binomial model was $<0.0001$. 
Table 2. Mean eosinophil, IgE, and CD4+ T cell levels according to intestinal parasitic infections in 105 HIV/AIDS individuals treated at the Specialized Outpatient Service and Day Hospital Professor Emeritus Domingos Alves Meira, UNESP, 2007-2008. The $p$ values obtained by adjusting a negative binomial model were $0.3198,0.3147$, and 0.0887 , respectively

\begin{tabular}{c|c|c|c}
\hline Variables & Infected & Non-infected & $\begin{array}{c}p<0.05 \text { values for adjustment of a } \\
\text { negative binomial model }\end{array}$ \\
\hline Eosinophils (cells $\left./ \mathrm{mm}^{3}\right)$ & 200.07 & 260.69 & 0.3198 \\
\hline $\lg \mathrm{(UI} / \mathrm{mL})$ & 882.3 & 559.3 & 0.3147 \\
\hline $\mathrm{CD} 4^{+} \mathrm{T}\left(\mathrm{cells} / \mathrm{mm}^{3}\right)$ & 596.2 & 412.8 & 0.0887 \\
\hline
\end{tabular}

IgE: immunoglobulin E

Table 3. Distribution of individuals with HIV/AIDS treated at the Specialized Outpatient Service and Day Hospital Professor Emeritus Domingos Alves Meira, UNESP, 2007-2008, according to detectable viral load and intestinal parasitic infections

\begin{tabular}{c|c|c|c|c|c}
\hline \multirow{2}{*}{ Viral Load } & \multicolumn{2}{|c|}{ Non-infected } & \multicolumn{2}{|c|}{ Infected } & \multirow{2}{*}{ p value for Fisher's exact test } \\
\cline { 2 - 5 } & $\mathbf{N}$ & $\%$ & $\mathbf{N}$ & $\%$ & \\
\hline Undetectable & 73 & 86.9 & 11 & 91.7 & \\
\hline$>50,000$ (copies $/ \mathrm{mL})$ & 11 & 13.1 & 1 & 8.3 & 0.6408 \\
\hline Total & 84 & 100.0 & 12 & 100.0 & \\
\hline
\end{tabular}

n: number; \%: percentage

(23.0\%), Endolimax nana in two (15.4\%), and Ascaris lumbricoides in one (7.7\%) (Figure 1).

\section{Analysis of Eosinophil Serum Levels}

Serum eosinophil levels for all patients varied from 0 to 1.948 cells $/ \mathrm{mm}^{3}$. Statistical analysis showed no significant difference between groups $(p=0.3198)($ Table 2$)$.

\section{Analysis of IgE Serum Levels}

Serum IgE levels varied from 1.8 to 7.060 UI/ $\mathrm{mL}$. Statistical analysis showed no significant difference between groups $(p=0.3147)$ (Table 2).

\section{Analysis of $\mathrm{CD}^{+} \mathrm{T}$ Cell Serum Levels}

Serum $\mathrm{CD}^{+} \mathrm{T}$ cell levels varied from 21 to 1,749 cells $/ \mathrm{mm}^{3}$. Statistical analysis showed no significant difference between groups $(p=0.0887)$ (Table 2).

\section{Analysis of Viral Load}

From individuals with negative diagnosis for intestinal parasites, 73 showed undetectable viral load levels $(<50.000$ copies $/ \mathrm{mL})$, and 11 showed a viral load $>50,000$ copies $/ \mathrm{mL}$ of blood.
Form those with positive diagnosis, 11 showed undetectable viral load levels $(<50,000$ copies/ $\mathrm{mL}$ ), and only one showed a viral load $>50,000$ copies/mL of blood (Table 3 ).

\section{Quantification of Serum Cytokines}

Statistical analysis showed a significant difference in relation to TNF- $\alpha(p=0.0277)$ and IL-5 $(p<0.0001)$ (Figure 2).

\section{DISCUSSION}

Studies relating AIDS patients to opportunistic infections have shown that HAART has contributed to HIV infection control and to the reconstitution of patient immune systems, leading to a reduction in the occurrence of opportunistic infections, including those caused by intestinal parasites (13-31).

Studies have connected serious or disseminated intestinal parasitic infections to immunosuppression, including AIDS, although several aspects remain obscure (12, 26, 32-37). This study aimed to better clarify the participation of intestinal parasites and their correlation with 


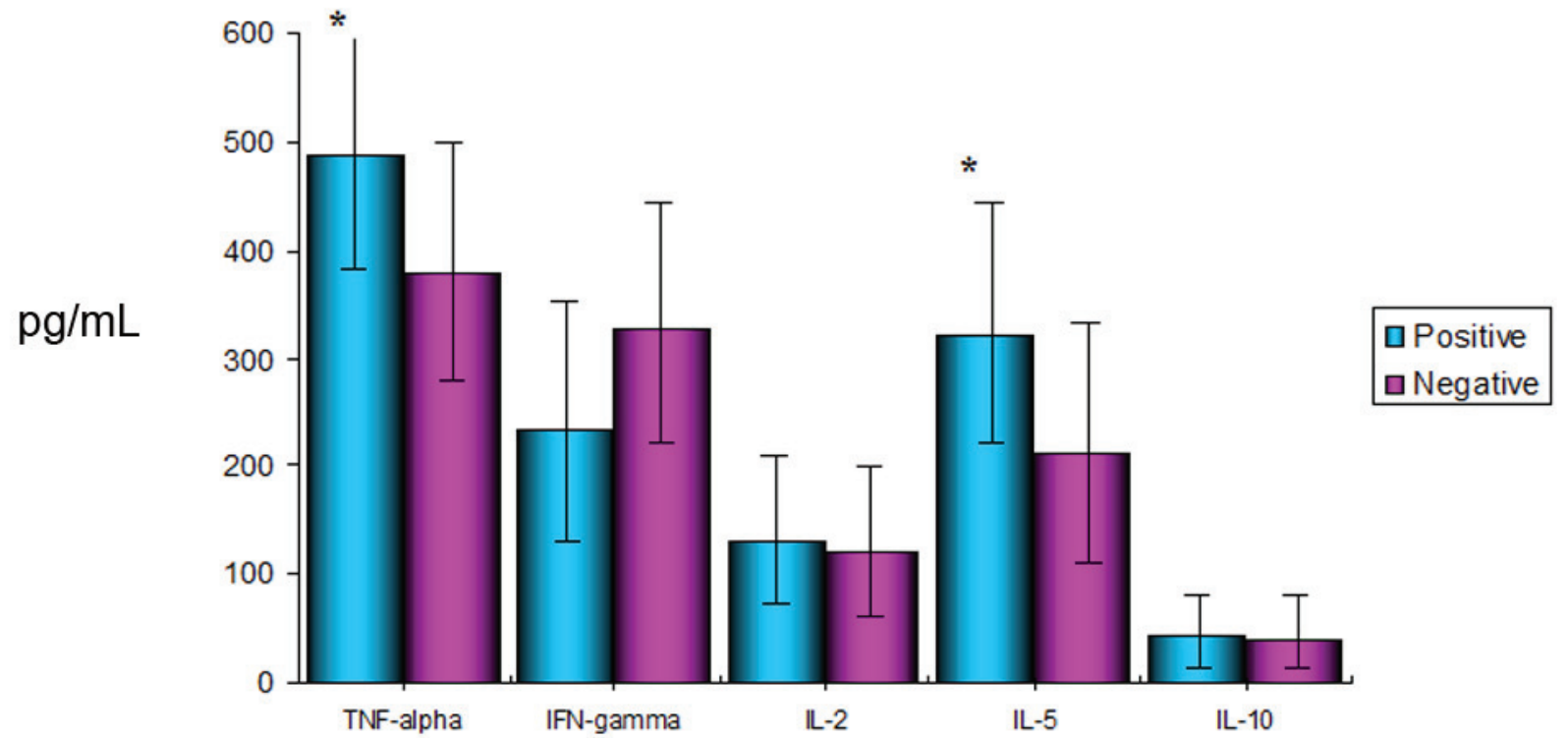

Figure 2. Mean TNF- $\alpha$, INF- $\gamma$, IL-2, IL-5, and IL-10 serum levels according to intestinal parasitic infections in HIV/AIDS individuals treated at the Specialized Outpatient Service and Day Hospital Professor Emeritus Domingos Alves Meira, UNESP, 2007-2008. The $p$ values were obtained by the Kruskal-Wallis test to compare infected and non-infected individuals for each cytokine.

immunity and nutrition levels in this patient group.

Various studies have associated intestinal parasites with education levels. In Brazil, this information has been used as an indirect measure of the socioeconomic situation, which shows, as regards HIV infection, an increased number of individuals with poorer education (38). In our study, $97.15 \%$ of the patients showed a good education level, thus better reflecting information and education levels in relation to various aspects, including parasitosis prevention. RodriguesJunior et al. (39) also reported schooling as an important variable in social stratification and concluded that the increased number of cases from social strata with poorer schooling is related to worse coverage by surveillance and care provision systems for individuals with less economically favored circumstances.

Another important aspect regarding the incidence of parasites is related to the presence or absence of basic sanitation. As concerns availability of treated water in the household, this study showed that $100 \%$ of the individuals dwelt in houses connected to the collective treated water supply network.

Fontbonne et al. (40) reported that housing type influences the number of different intestinal parasite species which affect members of a household. The majority of the population in our study lived in brick built houses in urban areas, thus agreeing with the authors that the role played by poverty can be seen by the fact that housing type influences the number of different species affecting household members. Only 26\% of our population reported using a vegetable garden as a food source, thus suggesting this as another indicator of low intestinal parasite prevalence.

Another important aspect is the participation of nutritional and immunity status in the presence of intestinal parasites. The presence of opportunistic infections in HIV individuals as well as the effects of drug treatment may aggravate or precipitate malnutrition conditions in this disease (41). When evaluating HIV patients under HAART, Schewenk et al. (42) observed that such treatment prevented malnutrition onset. Other researchers investigating the impact of HAART, through biochemical and nutritional indicators, observed that patients gained weight; showed an increased number of $\mathrm{CD} 4^{+} \mathrm{T}$ cells, reduced viral load, a reduced number of opportunistic infections, increased serum albumin, and consequently, a better quality of life (43). 
Our study population displayed good adherence to treatment $(88.5 \%)$, indicating increased survival and a reduced frequency in opportunistic diseases, including intestinal parasites. Several factors, such as service improvement and early diagnosis, in addition to HAART introduction, are involved in this scenario (44-47). Some studies have linked nutritional status to intestinal parasitic infections $(14,15$, 48). Authors have reported that individuals with compromised nutritional status followed by immunosuppression may have larger numbers of intestinal parasites and more severe infections (49). Nutrition is important when evaluating parasitic infections, particularly in malnourished individuals, who are more susceptible to severe and disseminated forms. This was not observed in our study in which $50 \%$ were eutrophic and $31.39 \%$ were overweight in the two groups.

Intestinal parasitic infections play an important role in individuals in general, particularly in those with immunosuppression (12). Disseminated strongyloidiasis has been reported in patients with sepsis and severe immunosuppression, which can even lead to death (50). The frequency of intestinal parasites in our study was $12.38 \%$. These findings agree with Cimerman et al. (12), who found a $12.3 \%$ frequency in both HIVpositive patients and HIV-negative individuals when evaluating patients in the post-HAART era.

Botero et al. (32) found a $32 \%$ frequency of parasites in a population with some type of immunological deficiency, including HIV infection. Reduced intestinal parasite prevalence has been observed in Brazil and worldwide since the early HAART years even when specific methods are included (51, 52). Bachur et al. (10) showed different frequencies for intestinal parasitic infections in the pre- and post-HAART eras. According to these authors, intestinal parasites were detected in $63.9 \%$ of patients from the pre-HAART era and $24 \%$ in the HAART era, thus showing a reduction in prevalence between the two periods. Cimerman et al. $(2,12)$ found a prevalence of $24.4 \%$ for opportunistic parasites in the pre-HAART era and $6.8 \%$ after HAART introduction, with higher rates in patients with $\mathrm{CD}^{+} \mathrm{T}$ cells $<200 / \mathrm{mm}^{3}$. When comparing periods before and after HAART implementation, Nobre et al. (13) observed prevalences of 2.8\% and $1.1 \%$, respectively, low in both eras, but even lower after HAART use. Different percentages found by various authors, including in this study, can be explained in various ways: sample number, population studied, type of tests and HAART, among others, as well as differences in the varying sources of intestinal parasite exposure.

In the present study, the patients showed a good socioeconomic level and good education; they lived in urban areas with basic sanitation, and a minority used a vegetable garden. Most were eutrophic or overweight, thus showing good nutritional status. Most patients were using HAART, and none showed opportunistic infections.

Intestinal infections, caused by a large variety of infectious agents, particularly helminths, produce eosinophilia especially in the acute phase (53-55). However, patterns and levels are determined by the development, migration, and distribution of the parasite in the host as well as by immune response. Defense against many of these parasitic infections is mediated by the activation of Th2 cells, which results in IgE antibody production and eosinophil activation. Although less frequent, HIV infection may be accompanied by moderate eosinophilia (56-59). Cytokines produced by Th2 cells promote eosinophil activation and recruitment to sites of helminth infection, where they release toxic granular proteins which destroy the parasites (60). Our study population showed varying eosinophil levels although the two groups did not present any difference; this can be explained by the individuals having good clinical, nutritional, and immunological status.

As regards IgE, previous studies have described that synthesis of this immunoglobulin is an important component of immune resistance against helminthic infections $(61,62)$. High serum IgE in individuals with AIDS were seen at the beginning of the epidemic and confirmed years later by other studies (63-69). Some studies have found a relationship between high $\operatorname{IgE}$ levels and $\mathrm{CD} 4^{+} \mathrm{T}$ lymphocyte count $<300$ cells/ $\mathrm{mm}^{3}(64-65,67)$. Association between increased IgE levels and faster progression to AIDS was observed by Rancinan et al. (69) in 1998. Total serum IgE levels were high in our study, particularly in infected patients, which suggests IgE participation in the induction and release process of histamine and other mediators in the immediate hypersensitivity reaction leading to helminth destruction (70).

In our study, both groups showed a mean 
$\mathrm{CD} 4^{+} \mathrm{T}$ lymphocyte count $\geq 400$ cells $/ \mathrm{mm}^{3}$. This indicates good immunological conditions, which explains, among other factors, the reduced number of parasitic infections, and is thus in agreement with the literature.

Most individuals in our study population had a viral load below the detection limit, thus showing control of the disease and good patient immunity levels. This shows that their disease was under control, with undetectable viral load and high $\mathrm{CD} 4^{+} \mathrm{T}$ cell levels, which certainly contributed to the smaller number of parasitic infections. Few studies have reported the relationship between cytokines in individuals with HIV and parasitic intestinal infections. Some authors evaluated cytokines and their relationship with parasites such as Schistosoma mansoni, Wuchereria bancrofti, and Trichinella spiralis (71-79). No correlation between serum INF- $\gamma$, IL- 2 , and IL10 levels and intestinal parasitic infections was seen. However, there was an increase in relation to the control of TNF- $\alpha$ and IL-5, also IL-5 has been associated with parasitic infections. TNF- $\alpha$ plays an inflammatory role, and it is also associated with cell loss during HIV infection. IL-5 is particularly important for the proliferation, growth, activation, and survival of eosinophils (80-84).

Therefore, the incidence of intestinal parasites in individuals with HIV/AIDS was very low. All patients had good socioeconomic and education levels, dwelt in urban areas with basic sanitation, and a minority used vegetable gardens. Most individuals were eutrophic or overweight; therefore of good nutritional status; most used HAART; and none had opportunistic infections. They showed good $\mathrm{CD}^{+} \mathrm{T}$ cell levels and low viral load which were compatible with their good immunity status, serum eosinophil levels within normal limits, and IgE levels above normality in both groups. Increased IL-5 and TNF- $\alpha$ levels were observed, thus showing a tendency toward Th2 profile and suggesting that the presence of intestinal parasitic infections may be contributing to alterations in immune response.

Further studies should be conducted in regions where basic sanitation and socioeconomic levels are poor and there are reduced $\mathrm{CD} 4^{+} \mathrm{T}$ cells for better comprehension of these variables.

\section{COPYRIGHT}

(c) CEVAP 2012

\section{SUBMISSION STATUS}

Received: December 20, 2011.

Accepted: March 8, 2012.

Abstract published online: March 9, 2012.

Full paper published online: May 31, 2012.

\section{CONFLICTS OF INTEREST}

The authors declare no conflicts of interest.

\section{ETHICS COMMITTEE APPROVAL}

This study was approved by the Research Ethics Committee of Botucatu Medical School, UNESP, under protocol number 147/2007-CEP. Moreover, all patients signed an informed consent form.

\section{CORRESPONDENCE TO}

Fátima Aparecida Mazzini Amâncio, Departamento de Doenças Tropicais e Diagnóstico por Imagem, Faculdade de Medicina de Botucatu, UNESP, Rubião Júnior, s/n, Botucatu, SP, 18.608-000, Brasil. Phone: +55 143811 6212. Email: famancio@fmb.unesp.br.

\section{REFERENCES}

1. WHO. World Health Organization. Joint united nations programme on HIV/AIDS (UNAIDS). AIDS epidemic update june 2008. Geneva: UNAIDS/WHO; 2008.

2. Cimerman S, Cimerman B, Lewi DS. Enteric parasites and AIDS. São Paulo Med J. 1999;117(6):266-73.

3. Arcoverde C, Magalhães V, Lima RA, Miranda C, Guedes I, Pascoal M, et al. Enteroparasitoses em pacientes infectados pelo vírus da imunodeficiência humana (HIV) atendidos no Hospital das Clínicas da UFPE. Rev Bras Anal Clin. 2004;36(1):13-7.

4. Arenas-Pinto A, Certad G, Ferrara G, Castro J, Bello MA, Núñez LT. Association between parasitic intestinal infections and acute or chronic diarrhoea in HIV-infected patients in Caracas, Venezuela. Int J STD AIDS. 2003;14(7):487-92.

5. Cimerman S, Cimerman B, Lewi DS. Avaliação da relação entre parasitoses intestinais e fatores de risco para o HIV em pacientes com AIDS. Rev Soc Bras Med Trop. 1999;32(2):181-5.

6. Gumbo T, Sarbah S, Gangaidzo IT, Ortega Y, Sterling $\mathrm{CR}$, Carville A, et al. Intestinal parasites in patients with diarrhea and human immunodeficiency virus infection in Zimbabwe. AIDS. 1999;13(7):819-21.

7. Moran P, Ramos F, Ramiro M, Curiel O, Gonzáles E, Valadez A, et al. Entamoeba histolytica and/or Entamoeba dispar: infection frequency in HIV+/AIDS patients in Mexico city. Exp Parasitol. 2005;110(3):3314.

8. Wuhib T, Silva TM, Newman RD, Garcia LS, Pereira ML, Chaves CS, et al. Cryptosporidial and microsporidial infections in human immunodeficiency virus-infected patients in northeastern Brazil. J Infect 
Dis. $1994 ; 170(2): 494-7$.

9. Neghme A, Silva R. Ecología del parasitismo en el hombre. Bol Oficina Sanit Panamam. 1971;70(4):31329.

10. Bachur TP, Vale JM, Coêlho IC, Queiroz TR, Chaves CdeS. Enteric parasitic infections in HIV/AIDS patients before and after the highly active antiretroviral therapy. Braz J Infect Dis. 2008;12(2):115-22.

11. Cimerman S, Cimerman B, Lewi DS. Prevalence of intestinal parasitic infections in patients with acquired immunodeficiency syndrome in Brazil. Int J Infect Dis. 1999;3(4):203-6.

12. Cimerman S, Castañeda CG, Juliano WA, Palacios R. Perfil das enteroparasitoses diagnosticadas em pacientes com infecção pelo vírus HIV na era da terapia antiretroviral potente em um centro de referência em São Paulo, Brasil. Parasitol Latinoam. 2002;57(3-4):111-9.

13. Nobre V, Braga E, Rayes A, Serufo JC, Godoy P, Nunes $\mathrm{N}$, et al. Opportunistic infections in patients with AIDS admitted to an university hospital of the southeast of Brazil. Rev Inst Med Trop São Paulo. 2003;45(2):6974.

14. Carvalho-Costa FA, Gonçalves AQ, Lassance SL, Silva Neto LM, Salmazo CAA, Bóia MN. Giardia lamblia and other intestinal parasitic infections and their relationships with nutritional status in children in Brazilian Amazon. Rev Inst Med Trop São Paulo. 2007;49(3):147-53.

15. Hadju V, Abadi K, Stephenson LS, Noor NN, Mohammed HO, Bowman DD. Intestinal helminthiasis, nutritional status, and their relationship; a cross-sectional study in urban slum school children in Indonesia. Southeast Asian J Trop Med Public Health. 1995;26(4):719-29.

16. Muniz-Junqueira MI, Queiroz EF. Relationship between protein-energy malnutrition, vitamin $\mathrm{A}$, and parasitoses in living in Brasília. Rev Soc Bras Med Trop. 2002;35(2):133-41.

17. Oberhelman RA, Guerrero ES, Fernandez ML, Silio M, Mercado D, Comiskey N, et al. Correlations between intestinal parasitosis, physical growth, and psychomotor development among infants and children from rural Nicaragua. Am J Trop Med Hyg. 1998;58(4):470-5.

18. Ordóñez LE, Angulo ES. Malnutrition and its association with intestinal parasitism among children from a village in the Colombian Amazonian region. Biomedica. 2002;22(4):486-98.

19. Quihui-Cota L, Valencia ME, Crompton DW, Phillips S, Hagan P, Diaz-Camacho SP, et al. Prevalence and intensity of intestinal parasitic infections in relation to nutritional status in Mexican schoolchildren. Trans $\mathrm{R}$ Soc Trop Med Hyg. 2004;98(11):653-9.

20. Shubair ME, Yassin MM, al-Hindi AI, al-Wahaidi AA, Jadallah SY, Abu Shaaban N al-D. Intestinal parasites in relation to haemoglobin level and nutritional status of school children in Gaza. J Egypt Soc Parasitol. 2000;30(2):365-75.

21. Grimble RF. Malnutrition and the immune response. 2. Impact of nutrients on cytokine biology in infection.
Trans R Soc Trop Med Hyg. 1994;88(6):615-9.

22. Brüssow H, Sidoti J, Dirren H, Freire WB. Effect of malnutrition in Ecuadorian children on titers of serum antibodies to various microbial antigens. Clin Diagn Lab Immunol. 1995;2(1):62-8.

23. Redmond HP, Gallagher HJ, Shou J, Daly JM. Antigen presentation in protein-energy malnutrition. Cell Immunol. 1995;163(1):80-7.

24. Kalinkovich A, Weisman Z, Greenberg Z, Nahmias J, Eitan S, Stein M, et al. Decreased CD4 and increased CD8 counts with $\mathrm{T}$ cell activation is associated with chronic helminth infection. Clin Exp Immunol. 1998;114(3):414-21.

25. Borkow G, Weisman Z, Leng Q, Stein $M$, Kalinkovich A, Wolday D, et al. Helminths, human immunodeficiency virus and tuberculosis. Scand J Infect Dis. 2001;33(8):568-71.

26. Bentwich Z, Weisman Z, Moroz C, Bar-Yehuda S, Kalinkovich A. Immune dysregulation in Ethiopian immigrants in Israel: relevance to helminth infections? Clin Exp Immunol. 1996;103(2):239-43.

27. Actor JK, Shirai M, Kullberg MC, Buller RM, Sher A, Berzofsky JA. Helminth infection results in decreased virus-specific CD8+ cytotoxic T-cell and Th1 cytokine responses as well as delayed virus clearance. Proc Natl Acad Sci USA. 1993;90(3):948-52.

28. Waitzberg DL, Ferrini MT. Exame físico e antropometria. In: Waitzberg DL, editor. Nutrição oral, enteral e parenteral na prática clínica. 3rd ed. São Paulo: Atheneu; 2004. 255-78 p.

29. WHO. Obesity: preventing and managing the global epidemic. Report of a WHO consultation. World Health Organ Tech Rep Ser. 2000;894(7):1-253.

30. World Health Organization. Obesity: preventing and managing the global epidemic: report of the WHO consultation on obesity, Geneva, Swtizerland, June 3-5, 1997. Geneva: WHO; 1998. 1-276 p.

31. Willemot P, Klein MB. Prevention of HIV-associated opportunistic infections and diseases in the age of highly active antiretroviral therapy. Expert Rev Anti Infect Ther. 2004;2(4):521-32.

32. Botero JH, Castaño A, Montoya MN, Ocampo NE, Hurtado MI, Lopera MM. A preliminary study of the prevalence of intestinal parasites in immunocompromised patients with and without gastrointestinal manifestations. Rev Inst Med Trop São Paulo. 2003;45(4):197-200.

33. Genta RM, Schad GA, Hellman ME. Strongyloides stercoralis: parasitological, immunological and pathological observations in immunosuppressed dogs. Trans R Soc Trop Med Hyg. 1986;80(1):34-41.

34. Igra-Siegman Y, Kapila R, Sen P, Kaminski ZC, Louria DB. Syndrome of hyperinfection with Strongyloides stercoralis. Rev Infect Dis. 1981;3(3):397-407.

35. Sneller $M$, Clifford $H$. Infections in the immunocompromised host. In: Rich R, editor. Clinical immunology principles and practices. London: Mosby; 1996. 579-93 p.

36. Porto AF, Neva FA, Bittencourt H, Lisboa W, Thompson R, Alcântara L, et al. HTLV-1 decreases Th2 type of immune response in patients with strongyloidiasis. 
Parasite Immunol. 2001;23(9):503-7.

37. Cimerman S, Cimerman B, Lewi DS. Conduta diagnóstica e terapêutica das parasitoses intestinais em pacientes portadores da infecção pelo HIV. Rev Bras Clin Terap. 1999;25(1):7-9.

38. Brasil. Ministério da Saúde. Coordenação Nacional de DST e AIDS. Políticas e diretrizes de prevenção das DST/AIDS entre mulheres. Brasília: Ministério da Saúde; 2003. 104 p.

39. Rodrigues-Junior AL, Castilho EA. A epidemia de AIDS no Brasil, 1991-2000: descrição espaçotemporal. Rev Soc Bras Med Trop. 2004;37(4):312-7.

40. Fontbonne A, Freese-de-Carvalho E, Acioli MD, Sá GA, Cesse EAP. Fatores de risco para poliparasitismo intestinal em uma comunidade indígena de Pernambuco, Brasil. Cad Saúde Pública. 2001;17(2):367-73.

41. Bates CM. HIV medicine: drug side effects and interactions. Postgrad Med J. 1996;72(843):30-6.

42. Schewenk A, Beisenherz A, Kremer G, Diehl V, Salzberger B, Fätkenheuer G. Bioelectrical impedance analysis in HIV-infected patients treated with triple antiretroviral treatment. Am J Clin Nutr. 1999;70(5):867-73.

43. Echeverria PS, Jonnalagadda SS, Hopkins BL, Rosenbloom CA. Perception of quality of life of persons with HIV/AIDS and maintenance of nutritional parameters while on protease inhibitors. AIDS Patient Care STDS. 1999;13(7):427-33.

44. Gadelha AJ, Accacio N, Costa RL, Galhardo MC, Cotrim MR, de Souza RV, et al. Morbidity and survival in advanced AIDS in Rio de Janeiro, Brazil. Rev Inst Med Trop São Paulo. 2002;44(4):179-86.

45. Rocha FMG. Política de prevenção ao HIV/AIDS no Brasil: o lugar da prevenção nessa trajetória [dissertation]. Rio de Janeiro: Escola Nacional de Saúde Pública, Fundação Oswaldo Cruz; 1999. 27 p.

46. Cechim PL, Selli L. Mulheres com HIV/AIDS: fragmentos de sua face oculta. Rev Bras Enferm. 2007;60(2):145-9.

47. Castanha AR, Coutinho MPL, Saldanha AAW, Ribeiro CG. Avaliação da qualidade de vida em soropositivos para o HIV. Estud Psicol. 2007;24(1):23-31.

48. Hagel I, Lynch NR, Di Prisco MC, Sanchez J, Pérez M. Nutritional status and the IgE response against Ascaris lumbricoides in children from a tropical slum. Trans $\mathrm{R}$ Soc Trop Med Hyg. 1995;89(5):562-5.

49. Paes RAP, Chieffi PP, Neto CDA. Estrongiloidíase disseminada na evolução fatal em crianças desnutridas. Rev Inst Adolfo Lutz. 1978;39(1):171-8.

50. Porto MAF, Muniz A, Oliveira Júnior J, Carvalho EM. Implicações clínicas e imunológicas da associação entre o HTLV-1 e a estrongiloidíase. Rev Soc Bras Med Trop. 2002;35(6):641-9.

51. Le Moing V, Bissuel F, Costagliola D, Eid Z, Chapuis F, Molina JM, et al. Decreased prevalence of intestinal cryptosporidiosis in HIV-infected patients concomitant to the widespread use of protease inhibitors. AIDS. 1998;12(11):1395-7.

52. Maggi P, Larocca AM, Quarto M, Serio G, Brandonisio O, Angarano G, et al. Effect of antiretroviral therapy on cryptosporidiosis and microsporidiosis in patients infected with human immunodeficiency virus type 1 . Eur J Clin Microbiol Infect Dis. 2000;19(3):213-7.

53. Moore TA, Nutman TB. Eosinophilia in the returning traveler. Infect Dis Clin North Am. 1998;12(2):503-21.

54. Weller PF. Eosinophilia in travelers. Med Clin North Am. 1992;76(6):1413-32.

55. Wilson ME, Weller PF. Eosinophilia. In: Guerrant RL, Walker DH, Weller PF, editors. Tropical infectious diseases: principles, pathogens, and practice. $1^{\text {st }}$ ed. Philadelphia: Churchill Livingstone; 1999. 1400-19.

56. Drabick JJ, Magill AJ, Smith KJ, Nutman TB, Benson PM. Hypereosinophilic syndrome associated with HIV infection. Military Medical Consortium for Applied Retroviral Research. South Med J. 1994;87(4):525-9.

57. Simpson-Dent S, Fearfield LA, Staughton RC. HIV associated eosinophilic folliculitis - differential diagnosis and management. Sex Transm Infect. 1999;75(5):291-3.

58. Skiest DJ, Keiser P. Clinical significance of eosinophilia in HIV-infected individuals. Am J Med. 1997;102(5):449-53.

59. Tietz A, Sponagel L, Erb P, Bucher H, Battegay M, Zimmerli W. Eosinophilia in patients infected with the human immunodeficiency virus. Eur J Clin Microbiol Infect Dis. 1997;16(9):675-7.

60. Abbas AK, Lichtman AH. Ativação da célula B e produção de anticorpos. In: Lichtman AH, Pillai AH, editors. Imunologia celular e molecular. 6 th ed. Rio de Janeiro: Elsevier; 2005. 212-4 p.

61. Lynch NR, Hagel IA, Palenque ME, Di Prisco MC, Escudero JE, Corao LA, et al. Relationship between helminthic infection and IgE response in atopic and nonatopic children in a tropical environment. J Allergy Clin Immunol. 1998; 101(2 Pt 1):217-21.

62. Hagel I, Lynch NR, Di Prisco MC, Rojas E, Pérez M, Alvarez N. Ascaris reinfection of slum children: relation with the IgE response. Clin Exp Immunol. 1993;94(1):80-3.

63. Ammann AJ, Abrams D, Conant M, Chudwin D, Cowan M, Volberding P, et al. Acquired immune dysfunction in homosexual men: immunologic profiles. Clin Immunol Immunopathol. 1983;27(3):315-25.

64. Wright DN, Nelson RP Jr, Ledford DK, FernandezCaldas E, Trudeau WL, Lockey RF. Serum IgE and human immunodeficiency virus (HIV) infection. J Allergy Clin Immunol. 1990;85(2):445-52.

65. Lucey DR, Zajac RA, Melcher GP, Butzin CA, Boswell RN. Serum IgE levels in 622 persons with human immunodeficiency virus infection: IgE elevation with marked depletion of CD4+ T-cells. AIDS Res Hum Retroviruses. 1990;6(4):427-9.

66. Israël-Biet $D$, Labrousse $F$, Tourani JM, Sors $H$, Andrieu JM, Even P. Elevation of IgE in HIV-infected subjects: a marker of poor prognosis. J Allergy Clin Immunol. 1992;89(1 Pt 1):68-75.

67. Small CB, McGowan JP, Klein RS, Schnipper SM, Chang CJ, Rosenstreich DL. Serum IgE levels in patients with human immunodeficiency virus infection. Ann Allergy Asthma Immunol. 1998;81(1):75-80.

68. Agarwal SK, Marshall GD Jr. In vivo alteration in type- 
1 and type- 2 cytokine balance: a possible mechanism for elevated total IgE in HIV-infected patients. Hum Immunol. 1998;59(2):99-105.

69. Rancinan C, Morlat P, Chêne G, Guez S, Baquey A, Beylot J, et al. IgE serum level: a prognostic marker for AIDS in HIV-infected adults? J Allergy Clin Immunol. 1998;102(2):329-30.

70. Else KJ, Finkelman FD. Intestinal nematode parasites, cytokines and effector mechanisms. Int J Parasitol. 1998;28(8):1145-58.

71. McElroy MD, Elrefaei M, Jones N, Ssali F, Mugyenyi P, Barugahare B, et al. Coinfection with Schistosoma mansoni is associated with decreased HIV-specific cytolysis and increased IL-10 production. J Immunol. 2005;174(8):5119-23.

72. Nielsen NO, Friis H, Magnussen P, Krarup H, Magesa S, Simonsen PE. Co-infection with subclinical HIV and Wuchereria bancrofti, and the role of malaria and hookworms, in adult Tanzanians: infection intensities, CD4/CD8 counts and cytokine responses. Trans R Soc Trop Med Hyg. 2007;101(6):602-12.

73. Vallance BA, Blennerhassett PA, Deng Y, Matthaei KI, Young IG, Collins SM. IL-5 contributes to worm expulsion and muscle hypercontractility in a primary T. spiralis infection. Am J Physiol. 1999;277(2 Pt1):G400-8.

74. Borkow G, Bentwich Z. Chronic immune activation associated with chronic helminthic and human immunodeficiency virus infections: role of hyporesponsiveness and anergy. Clin Microbiol Rev. 2004;17(4):1012-30.

75. Bentwich Z. Concurrent infections that rise the HIV viral load. J HIV Ther. 2003;8(3):72-5.

76. Fincham JE, Markus MB, Adams VJ. Could control of soil-transmitted helminthic infection influence the HIV/AIDS pandemic. Acta Trop. 2003;86(2-3):31533.
77. Brown M, Kizza M, Watera C, Quigley MA, Rowland $\mathrm{S}$, Hughes $\mathrm{P}$, et al. Helminth infection is not associated with faster progression of HIV disease in coinfected adults in Uganda. J Infect Dis. 2004;190(10):1869-79.

78. Elliott AM, Mawa PA, Joseph S, Namujju PB, Kizza $\mathrm{M}$, Nakiyingi JS, et al. Associations between helminth infection and $\mathrm{CD} 4+\mathrm{T}$ cell count, viral load and cytokine responses in HIV-1-infected Ugandan adults. Trans R Soc Trop Med Hyg. 2003;97(1):103-8.

79. Brown M, Bukusuba J, Hughes P, Nakiyingi J, Watera C, Elliott A, et al. Screening for intestinal helminth infestation in a semi-urban cohort of HIV-infected people in Uganda: a combination of techniques may enhance diagnostic yield in the absence of multiple stool samples. Trop Doct. 2003; 33(2):72-6.

80. Takamoto M, Ovington KS, Behm CA, Sugane K, Young IG, Matthaei KI. Eosinophilia, parasite burden and lung damage in Toxocara canis infection in C57BI/6 mice genetically deficient in IL-5. Immunology. 1997;90(4):511-7.

81. Weller PF. Eosinophils: structure and functions. Curr Opin Immunol. 1994;6(1):85-90.

82. Sanderson CJ. Interleukin-5: an eosinophil growth and activation factor. Dev Biol Stand. 1988;69(1):23-9.

83. Simon HU, Blaser K. Inhibition of programmed eosinophil death: a key pathogenic event for eosinophilia? Immunol Today. 1995;16(2):53-5.

84. Stern M, Meagher L, Savill J, Haslett C. Apoptosis in human eosinophils. Programmed cell death in the eosinophil leads to phagocytosis by macrophages and is modulated by IL-5. J Immunol. 1992;148(11):35439. 